\title{
Erratum to: Neonatal outcomes of Syrian refugees delivered in a tertiary hospital in Ankara, Turkey
}

Mehmet Büyüktiryaki, Fuat Emre Canpolat*, Evrim Alyamaç Dizdar, Nilüfer Okur and Gülsüm Kadıoğlu Şimşek

\section{Erratum}

Unfortunately, the original version of this article [1] contained an error.

The sentence "The Turkish neonatal mortality rate is $0.04 \%$ according to World Health Organization Reports and the Ministry of Health of Turkey (http://www.saglik. gov.tr/TR/dosya/1-97020/h/saglik-istatistik-yilligi-2013.pdf)" should have read "The Turkish neonatal mortality rate is $0.4 \%$ according to the Ministry of Health of Turkey (http:// www.saglik.gov.tr/TR/dosya/1-97020/h/saglik-istatistik-yilligi -2013.pdf)".

The corrected sentence has been included in full in this erratum.

Received: 22 July 2016 Accepted: 22 July 2016

Published: 29 July 2016

\section{References}

1. Büyüktiryaki M, Canpolat FE, Alyamaç Dizdar E, Okur N, Kadıoğlu Şimşek G. Neonatal outcomes of Syrian refugees delivered in a tertiary hospital in Ankara, Turkey. Confl Heal. 2015;9:38. doi:10.1186/s13031-015-0066-1.

Submit your next manuscript to BioMed Central and we will help you at every step:

- We accept pre-submission inquiries

- Our selector tool helps you to find the most relevant journal

- We provide round the clock customer support

- Convenient online submission

- Thorough peer review

- Inclusion in PubMed and all major indexing services

- Maximum visibility for your research

Submit your manuscript at www.biomedcentral.com/submit 